\title{
THE EU AND RESPONSIBILITY TO PROTECT: CASE STUDIES ON THE EU'S RESPONSE TO MASS ATROCITIES IN LIBYA, SOUTH SUDAN AND MYANMAR
}

\author{
Darina Dvornichenko \\ Vadym Barskyy ${ }^{* *}$
}

\begin{abstract}
The article is devoted to the study of the evolution of the European Union (EU) approach towards the Responsibility to Protect $(R 2 P)$. The paper refers to the case study method used to assess the EU's capacity to respond adequately to the particular mass atrocity cases - Libya, South Sudan, and Myanmar. The methodology of the paper is based on a discursive analytical approach, which requires a thorough examination of the official declarations, statements, and resolutions adopted by the $E U$ in the scope of EU foreign and security policy. The article focuses on clear distinctions between the EU's approach to these cases, reveals several weaknesses and hidden reputational risks in the EU's response to mass atrocity situations as well as offers several recommendations on how to overcome identified deficiencies.
\end{abstract}

KEYWORDS: EU, Mass Atrocities, Responsibility to Protect, Libya, Myanmar, South Sudan.

\section{INTRODUCTION}

The EU is a highly integrated and influential block in Europe, with a normative reach that increasingly seeks to go beyond its borders. Through its significant attraction, pressure and persuasion, the Union increasingly claims to

* Darina Dvornichenko, National University “Odessa Maritime Academy" Maritime Law Department, Ukraine; darina.dvornichenko@gmail.com.

** Vadym Barskyy, Odessa I.I. Mechnikov National University Civil Law Department, Ukraine; vadym.barskyy@gmail.com. 
be a global actor and agent of change outside its borders. Alongside with the substantial soft power through conflict resolution and development assistance, the EU also possesses the ability to use coercive power through sanctions and military interventions. By creating the idea of a global actor, the EU sends the messages that it is capable to fight against any injustice outside its borders as well as assumes its part of the responsibility for global security. However, some critics argue that the Union's response to particular mass atrocity situations shows a gap between EU rhetoric and action. Others emphasize that the EU fuels unrealistic expectations as to its role in preventing mass atrocities.

The aim of this paper is to conduct a comprehensive study of the evolution of the EU approach towards the R2P as well as to assess the EU's capacity to act quickly and decisively in actual mass atrocity situations that occurred in Libya, South Sudan and Myanmar.

This paper strives to provide answers to the following three questions: whether the scope of the EU's commitment to R2P is understood and perceived similarly by the key EU's institutions based on the analysis of the official documents and statements; how the understanding of the EU's commitment to the $\mathrm{R} 2 \mathrm{P}$ is reflected in Union's response to the actual situations of mass atrocities based on the analysis of three cases; to what extent the EU's tools and policies are adequate in three cases.

The methodology used in the paper is a discursive analytical approach, which requires a thorough examination of the official declarations, statements, and resolutions adopted by the EU in the scope of EU foreign and security policy. These documents will allow not only to examine the EU's role it seeks to perform but also to observe key patterns, trends, and changes in the EU official position towards its responsibility for global security. Alongside the qualitative content analysis of relevant documents and official statements, we rely on Uppsala Conflict Data Program (Violence Dataset) as our primary source for collecting data on the peaks of mass atrocity incidents which constitute a time frame for analyzing EU's response. The paper refers to the case study method used to assess the EU's capacity to respond adequately to the particular mass atrocity cases. We then offer a comparative analysis to identify and explain existing variation in terms of EU responses to mass atrocities in our three cases - Libya (2011-2012), South Sudan (2014-2015), and Myanmar (20172018).

The issues which this paper addresses belong to a broader debate of the role of the EU as a global actor and agent of change in international relations. This issue has been addressed by Charlotte Bretherton and John Vogler ${ }^{1}$, Ian Man-

Bretherton C., Vogler, J.: The European Union as Global Actor, 2nd Edition, London, Routledge, 2006, 273 p. 
ners ${ }^{2}$, etc. In this regard, the vast majority of literature focuses on the EU's potential to act as a normative power. However, there is a number of scholars examining the potential of the EU for peace-building or achieving its goals through funding such as Faria Fernanda and Richard Youngs ${ }^{3}$, Nathalie Tocci ${ }^{4}$ and Jonathan Spyer ${ }^{5}$. Nonetheless, few scholars have examined the effectiveness of the EU foreign policy instruments in the fight against mass atrocities (e.g. Karen E. Smith ${ }^{6}$, Jan Wouters, Philip De Man, and Marie Vincent ${ }^{7}$ ).

The significance of this paper lies in its implications for the EU. A thorough understanding of the EU's foreign policy will allow Brussels to select the most appropriate modalities of engagement as well as develop the most efficient mechanisms for countering mass atrocity crimes.

\section{OVERVIEW OF THE EU'S APPROACH TOWARDS FIGHT AGAINST MASS ATROCITIES}

The EU has been perceived as a particularly suitable candidate for preventing egregious human rights violations. Besides, given that mass atrocities are understood as the anti-thesis to development, the EU, as the world's biggest aid donor, is perceived as a key player in the nexus believed by some to exist between development and mass atrocity prevention.

Since the beginning of the new century, the EU has made considerable progress in affirming its role as an international actor willing to act in mass atrocity cases. The European Security Strategy "A Secure Europe in a Bet-

2 Manners, I.: Normative Power Europe Reconsidered: Beyond the Crossroads, Journal of European Public Policy, 13(2) 2006.

3 Fernanda, F., Youngs, R.: European Conflict Resolution Policies: Truncated Peacebuilding, Fride Working Paper, 2010, [https://www.files.ethz.ch/isn/131019/WP94_UE_Paz_Construccion_ENG_mar10.pdf ], accessed on 03/11/2019.

4 Tocci, N.: Regional origins, global aspirations: the European Union as a global conflict manager, in: Stefan Wolff and ChristallaYakinthou (eds.), Conflict Management in Divided Societies. Theories and Practice, London and New York, Routledge, 2011, p. 135-150.

5 Spyer, J.: Europe and Iraq: Test Case for the Common Foreign and Security Policy, Middle East Review of International Affairs, 11(2) 2007.

6 Smith, K.: Still “Civilian Power EU”?, European Foreign Policy Unit Working Paper, European Foreign Policy Unit Working Paper, No. 1/2005, [https://www.dahrendorf-forum.eu/ wp-content/uploads/2018/08/EU-and-RTP-in-an-illiberal-era.pdf], accessed on 05/11/2019.

7 Wouters, J., De Man, Ph., Vincent, M.: The Responsibility to Protect: Where Does the EU Stand? Policy Brief No. 10 - November 2008, [https://www.researchgate.net/publication/228684679_The_Responsibility_to_Protect_Where_Does_the_EU_Stan], accessed on 05/11/2019. 
ter World"8 brought the first novelty in the scope of EU foreign and security policy ambitions. Drafted in mid-2003 and agreed formally by the European Council in December 2003, the European Security Strategy made it clear that none of the threats could be addressed with purely military means, and that preventive engagement is the best way to try to ensure that situations do not escalate or deteriorate. The European Security Strategy calls for more coherent policies, bringing together different instruments including aid, military capabilities, trade, and so on. There is a shared and clear preference to intervene earlier with a broad range of instruments and thus perhaps reduce the need to use military means. However, the critics argued that the adoption of the European Security Strategy did not make clear the issue of how the EU would protect civilians in case of mass atrocities ${ }^{9}$. Even though the European Security Strategy considered human security as a priority, there was no mention of the role the EU could play in such situations as genocide in order to save the affected population. This issue was addressed less than a year later. As part of the Headline Goal 2010 approved by General Affairs and External Relations Council on 17 May 2004, the EU embarked on a new challenge of creating ten rapid reaction battle-groups that could potentially act in situations concerning the protection of civilians ${ }^{10}$.

At the 2005 World Summit, the EU members expressed their endorsement and support of R2P which suggests that states have the primary responsibility to protect their populations (Pillar One), but also that the international community should assist states in this duty (Pillar Two) and when a state is unable or unwilling to protect its population from genocide, ethnic cleansing, war crimes and/or crimes against humanity, the international community should do so through any appropriate means (Pillar Three) ${ }^{11}$. R2P thus emerged as a vehicle for cementing obligations of host and third-party states to ensure consistent and effective human protection from mass atrocity crimes ${ }^{12}$.

8 European Union (2003), A Secure Europe in a Better World: European Security Strategy, Brussels, [https://europa.eu/globalstrategy/en/european-security-strategy-secure-europe-better-world], accessed on 03/11/2019.

9 Biscop, S.: The European Security Strategy: A Global Agenda for Positive Power, Aldershot, Ashgate Publishing, 2005, p. 26.

10 Council Press Release (2004), General Affairs and External Relations, Luxembourg. [https://www.consilium.europa.eu/ueDocs/cms_Data/docs/pressdata/en/gena/80498.pdf], accessed on 03/11/2019.

11 United Nations General Assembly (2005) Resolution № 60/1: 2005 World Summit Outcome, [http://www.un.org/en/development/desa/population/migration/generalassembly/ docs/globalcompact/A_RES_60_1.pdf], accessed on 03/11/2019.

12 Nahlawi, Y. The responsibility to Protect in Libya and Syria: Mass Atrocities, Human Protection and International Law, Routledge, 2019, p. 172 
A year later, the EU, as the biggest provider of development aid, signed "the European Consensus on Development" in 2006, in which all three of the principal EU institutions declared that they "cannot stand by, as genocide, war crimes, ethnic cleansing or other gross violations of international humanitarian law and human rights are committed". The EU affirmed its willingness to support "a strengthened role for the regional and sub-regional organizations in the process of enhancing international peace and security, including their capacity to coordinate donor support in the area of conflict prevention"13.

In 2008, the EU issued a report on the implementation of the European Security Strategy "Providing Security in a Changing World" which identified the key threats facing the Union and defines its strategic objectives. This document refers directly to the necessity for all states to "take responsibility for the consequences of their actions and hold a shared responsibility to protect populations from genocide, war crimes, ethnic cleansing and crimes against humanity" 14 .

In the second decade of the XXI century the key EU institutions in this areaEuropean Council, Commission, European Parliament, and Council -propose diverging conceptions dividing them on the issue of the interpretation of the R2P principle.

The European Parliament, considering the R2P a preventive doctrine and military intervention the last resort in R2P situations, emphasizes its preference for diplomatic and long-term developmental activities. Its recommendation to the Council of 18 April 2013 on the UN principle of the 'Responsibility to Protect' ('R2P') ${ }^{15}$ suggests integrating the R2P principle in the EU's development assistance and including a chapter in the HR/VP's annual report to Parliament on the CFSP concerning the EU's actions in applying the R2P principle. The focus on capacity-building in the fields of human rights, good governance, the rule of law, the reduction of poverty, and ensuring education alongside the non-military coercive alternatives, such as preventive diplomacy, sanctions, accountability mechanisms, and mediation is repeated in the

13 European Parliament, Council and Commission (2006), Joint statement by the Council and the representatives of the governments of the Member States meeting within the Council, the European Parliament and the Commission on European Union Development Policy: 'The European Consensus', [https://eur-lex.europa.eu/LexUriServ/LexUriServ.do?uri=OJ\%3AC\%3 A2006\%3A046\%3A0001\%3A0019\%3AEN\%3APDF], accessed on 10/11/2019.

14 Council Report on the Implementation of the European Security Strategy (2008), Providing Security in a Changing World, Brussels [https://www.consilium.europa.eu/ ueDocs/cms_Data/docs/pressdata/EN/reports/104630.pdf], accessed on 09/11/2019.

15 European Parliament Recommendation to the Council of 18 April 2013 on the UN principle of the 'Responsibility to Protect' ('R2P'). [https://www.europarl.europa.eu/sides/getDoc. do?reference=P7-TA-2013-0180\&type=TA\&language=EN\&redirect], accessed on 09/11/2019. 
present recommendation and subsequent resolutions ${ }^{16}$.

The Commission in its Joint Communication on the EU's Comprehensive Approach to External Conflict and Crises in $2013^{17}$ sets out its understanding of the EU's comprehensive approach as a way to react to external conflict, including those which possess a high risk of mass atrocities. Joint Communication which refers to the EU as the world's largest trading block names a wide array of policies, tools, and instruments at the EU's disposal-spanning the diplomatic, security, defense, financial, trade, development cooperation, and humanitarian aid fields.

The Council in its Conclusions on the EU's comprehensive approach dated $2014^{18}$, on the other hand, reiterates the important role of CSDP, including its civilian and military expertise and civilian-military synergies, as an essential element in the EU's comprehensive approach and emphasized the need for the EU to better, earlier and more systematically link up its political engagement and its CSDP missions and operations. The particular emphasis is made on the ability to play a positive and transformative role in its external relations and act as a global actor.

The European Council in its Global Strategy for the European Union's Foreign and Security Policy adopted in $2016^{19}$ stated that the EU will also promote the responsibility to protect in order to prevent or end mass atrocities. Besides, it signaled that building the resilience of societies would help prevent conflicts and crises.

At the 2018 debate on the R2P at the UN General Assembly, the EU ambassador once again confirmed that the EU was born "in a spirit of "never again"" and so the R2P "is at the core of our primary goal, namely to allow our populations to live in peace and security" 20 .

16 European Parliament Resolution of 16 December 2015 on preparing for the World Humanitarian Summit: Challenges and opportunities for humanitarian assistance, [https://eurlex.europa.eu/legal-content/EN/TXT/PDF/?uri=CELEX:52015IP0459\&from=EN], accessed on $09 / 11 / 2019$.

17 European Parliament and Council (2013), Joint communication. The EU's comprehensive approach to external conflict and crises, [https://eur-lex.europa.eu/legal-content/en/TX$\mathrm{T} /$ ?uri=CELEX\%3A52013JC0030].

18 Council Conclusions on the EU's comprehensive approach, of 12 May 2014, [https://www. consilium.europa.eu/media/28344/142552.pdf], accessed on 10/11/2019.

19 European Union (2016), Shared Vision, Common Action: A Stronger Europe. A Global Strategy for the European Union Foreign and Security Policy, Luxembourg, [http://europa. eu/globalstrategy/sites/globalstrategy/files/regions/files/eugs_review_web_0.pdf], accessed on 10/11/2019.

20 European External Action Service (2018b), Statement on behalf of the EU and its Member States by Ambassador Joanne Adamson, Deputy Head of Delegation, at the UN Gener- 
Three case studies - Libya, South Sudan, and Myanmar - will help us to assess the EU's capacity to act quickly and decisively in actual mass atrocity situations. These three cases were selected taking into account the fact the EU has the potential to have a particular influence there. Libya, South Sudan and Myanmar are not the locations of intensive outside intervention contrary to Syria and the countries concerned had been the subject of EU foreign policies before violence erupted.

\section{THE CASE STUDY}

\subsection{THE LIBYA CASE}

The conflict in Libya started in 2011 with the arrest of civil rights activists which quickly developed into the full-scale protests and eventually led to a civil war. As soon as the Libyan government responded violently to the rebellion against it, the international community reacted by invoking R2P's measure of last resort.

In March 2011, the European Parliament condemned in the strongest terms the blatant and systemic violations of human rights in Libya and stressed that the EU and its Member States must honor their Responsibility to Protect, to save Libyan civilians from large-scale armed attacks ${ }^{21}$. In September 2011, in response to the fall of Gaddafi, the European Parliament adopted a resolution that welcomed the collapse of the former regime and expressed the full support to the interim authority of the Libyan National Transitional Council. The resolution also stressed that there should be no impunity for crimes against humanity and that Muammar Gaddafi and members of his regime must be held responsible and put to trial for their crimes under the rule of $1 \mathrm{law}^{22}$.

Apart from the European Parliament resolutions, the European Commission reacted to the Libyan crisis by launching two of its major emergency instruments: the civil protection mechanism and humanitarian assistance. Activated

al Assembly Debate on "The responsibility to protect and the prevention of genocide, war crimes, ethnic cleansing and crimes against humanity", [https://eeas.europa.eu/headquarters/headquarters-homepage/47293/ debate-responsibility-protect-and-prevention-genocide-war-crimes-ethnic-cleansing-and-crimes_en], accessed on 10/11/2019.

21 European Parliament (2011a) Resolution of 10 March 2011 on the Southern Neighbourhood, and Libya in particular,[http://www.europarl.europa.eu/sides/getDoc.do?pubRef=-//EP// TEXT+TA+P7-TA-2011-0095+0+DOC+XML+V0//EN], accessed on 05/12/2019.

22 European Parliament (2011b) Resolution of 15 September 2011 on the situation in Libya, [http://www.europarl.europa.eu/sides/getDoc.do?type=TA\&language=EN\&reference $=$ P7-TA-2011-386] accessed on 05/12/2019. 
on 23 February 2011, the civil protection mechanism facilitated member state consular operations by pooling and identifying transport means for the evacuation of an estimated 5,800 EU citizens. However, these actions provoked strong criticism as the EU Commissioner for International Cooperation, $\mathrm{Hu}$ manitarian Aid and Crisis Response Kristalina Georgieva ${ }^{23}$ was one of many who reminded the EU of its Responsibility to protect not only its own citizens but also the Libyan population. Besides, within the framework of the European Commission humanitarian aid department (ECHO), €150,799, 072 has been contributed by the EU for humanitarian aid and civil protection ${ }^{24}$. Alongside the humanitarian aid, in 2011 the Strategy for Security and Development in the Sahel had announced EUR 24.5 million in EU assistance to Libya, allocated under the European Development Fund, Instrument for Stability, European Neighbourhood Policy Instrument, thematic programs, and budget lines.

Most importantly, the EU adopted sanctions against Libya on February 28, $2011^{25}$. The Council Decision 2011/137/CFSP introduced arms embargo, assets freeze \& travel bans against individuals and entities. The Council also adopted the Regulation No 204/2011 in order to implement the measures provided for in Council Decision 2011/137/CFSP that fall under the competence of the Union. It requires the Member States to determine the penalties applicable to infringements of their provisions. ${ }^{26}$ Although both these documents do not contain any mentioning of "mass atrocities", the restrictive measures were adopted in the light of "serious human rights abuses".

Condemning "the gross and systematic violation of human rights, violence, and brutal repression" ${ }^{27}$, the Council adopted the decision on the launch of EUFOR Libya military operation to support humanitarian assistance opera-

23 European Union (2011), Statement by Kristalina Georgieva, Commissioner for International Cooperation, Humanitarian Aid and Crisis Response, on the deteriorating humanitarian situation in Misrata, Libya. [https://reliefweb.int/report/libya/statement-kristalina-georgieva-commissioner-international-cooperation-humanitarian-aid], accessed on 05/12/2019.

24 European Commission Official Website: European Commission Humanitarian Aid and Civil Protection, [https://ec.europa.eu/echo/files/aid/countries/libya_factsheet.pdf], accessed on $05 / 12 / 2019$.

25 Council Decision No 2011/137/CFSP of 28 February 2011 concerning restrictive measures in view of the situation in Libya, [https://eur-lex.europa.eu/LexUriServ/LexUriServ.do?uri=OJ:L:2011:058:0053:0062:EN:PDF], accessed on 05/12/2019.

26 Council Regulation No 204/2011 of 2 March 2011 concerning restrictive measures in view of the situation in Libya, [https://eur-lex.europa.eu/legal-content/EN/TXT/PDF/?uri=CELEX:32011R0204\&from=EN], accessed on 05/12/2019.

27 Council Decision No 2011/210/CFSP of 1 April 2011 on a European Union military operation in support of humanitarian assistance operations in response to the crisis situation in Libya (EUFOR Libya), [https://eur-lex.europa.eu/LexUriServ/LexUriServ.do?uri=O$\mathrm{J}: L: 2011: 089: 0017: 0020: E N: P D F]$, accessed on 05/12/2019. 
tions. However, the Decision was not implemented as there was no UN call for such use, and some EU battle groups member states $\left(S_{w e d e n}{ }^{28}\right)$ were not willing to act.

The actual test for the EU unity took place on 17 March 2011 when the United Nations Security Council adopted the Resolution 1973 which authorized "to take all necessary means to protect civil population" -although specifically "excluding a foreign occupation force of any form on any part of Libyan territory", but including the possibility of a limited air intervention. While three EU members of the Security Council voted in favor, the forth - Germany abstained. This publicly displayed disunity over a vital conflict in Europe's direct vicinity amounts to the disintegration of Europe as a political actor ${ }^{29}$. The outcome of the deep disagreements among leading EU member-states led to the situation when the EU's CSDP was excluded from the tools available to the EU to address the Libya crisis. The member-states did not rely on the CSDP even when it came to evacuating EU citizens. The evacuation was carried out by the EU member-states ${ }^{30}$.

The Libya crisis is considered a first foreign-security test for the Lisbon Treaty, European security culture, and the R2P. Critics argue that the EU's response to it was too weak and incoherent. As Nicole Koenig clearly states "while there has been a multifaceted EU response to the Libyan crisis, nearly every facet of this response was marked by vertical incoherence" ${ }^{31}$. However, the Libya crisis was the first one that explicitly demonstrated the EU's understanding of the $\mathrm{R} 2 \mathrm{P}$ as the prevention and re-building rather than military protection.

\subsection{THE SOUTH SUDAN CASE}

South Sudan gained its independence in 2011. However, in 2013, civil war broke out between rival political and ethnic groups. It is estimated that up to 300,000 people have been killed. In December 2013, UN Special Adviser on the Prevention of Genocide, Adama Dieng, and the UN Special Adviser on

28 Dembinski, M., \& Reinold, T.: Libya and the Future of the Responsibility to Protect African and European Perspectives, Peace Research Institute Report, Frankfurt, 2011, p.11, [https://www.hsfk.de/fileadmin/HSFK/hsfk_downloads/prif 107.pdf], accessed on 03/12/2019.

29 Stavridis, $S$., EU incoherence and inconsistency over Libya: evidence to the contrary. Cahiers de la Méditerranée, 89 2014, p.165.

30 Fabbrini, S.: The European Union and the Libyan crisis. International Politics, 51(2) 2014, [https://www.researchgate.net/publication/263326293_The_European_Union_and_the_Libyan_crisis], accessed on 03/12/2019.

31 Koenig, N.: The EU and the Libyan Crisis: In Quest of Coherence, The International Spectator, 46 (4), 2011, p. 10, [https://www.tandfonline.com/doi/full/10.1080/03932729.2011.62808 9?scroll=top\&need Access $=$ true], accessed on 03/12/2019. 
the Responsibility to Protect, Jennifer Welsh, expressed their concern about the ethnic-based violence and warned that attacks on civilians could constitute war crimes and crimes against humanity ${ }^{32}$.

The EU's language, on the contrary, was more reserved. The European Parliament in the resolution of 13 November 2014 calls upon the international community to hold accountable those who perpetrated "gross human rights" 33 , while the Council Regulation adopted in 2015 points at "serious human rights violations", 34

Talking about the EU's actual response, here Brussels has used a vast array of tools. In 2012 the Council of the EU agreed to deploy a civilian CSDP mission, EUVASEC, which consisted of 60 personnel members and aimed at improving aviation security at Juba international airport. However, at the outbreak of the civil war, the mission was evacuated in 2013 and the member states failed to renew it. Besides, in 2013 when the civil war had already started the EU terminated the mandate of the EU Special Representative to Sudan and South Sudan. ${ }^{35}$

Though within the period in question - 2014-2015- the EU did not rely on the CSDP component, it was quite active in humanitarian policies. Humanitarian aid from the EU to South Sudan amounted to $€ 95$ million. ${ }^{36}$ The European Commission also presented an ad hoc programming document for the $€ 150$ million Special Funds for Sudan program. Additional funding dependent on the accession of South Sudan to the Cotonou Agreement (which in its turn requires from the countries respect of human rights, democratic principles and the rule of law) could also be provided to South Sudan through the European Development Fund. In 2014 due to the non-accession of South Sudan to the

32 United Nations Press Release (2013), Statement by Adama Dieng, United Nations Special Adviser on the Prevention of Genocide, and Jennifer Welsh, United Nations Special Adviser on the Responsibility to Protect, on the Situation in South Sudan, [http://www.un.org/en/genocideprevention/documents/media/statements/2013/English/2013-12-24-Statement\%20on\%20 South\%20Sudan.pdf], accessed on 05/12/2019.

33 European Parliament Resolution of 13 November 2014 on the humanitarian situation in South Sudan, [https://www.europarl.europa.eu/doceo/document/TA-8-2014-0053_EN.html], accessed on 05/12/2019.

34 Council Regulation No 2015/735 of 7 May 2015 concerning restrictive measures in respect of the situation in South Sudan, and repealing Regulation (EU) No 748/2014, [https://eur-lex. europa.eu/legal-content/EN/TXT/PDF/?uri=CELEX:32015R0735], accessed on 05/12/2019.

35 Smith, K.: The EU and the Responsibility to Protect in an Illiberal Era. Dahrendorf Forum Working Paper, 3, 2018, p. 19

[http://eprints.lse.ac.uk/90083/1/Smith_EU-Responsibility-to-Protect_Published.pdf], accessed on 11/12/2019.

36 European Commission Official Website: South Sudan factsheet, [https://ec.europa.eu/ echo/where/africa/south-sudan_en], accessed on 11/12/2019. 
Cotonou Agreement, it did not have the right to development assistance of the 10th European Development Fund (EDF), which amounted to 300 million euros for the period 2008-2013. However, it did not prevent the EU from providing left-over funds from the 9th EDF to South Sudan ${ }^{37}$.

The EU also acted as the lead mediator to empower the Intergovernmental Authority on Development (IGAD), an eight-country regional bloc. In August 2015, when the "Agreement on the Resolution of the Conflict in South Sudan" (ARCSS) was signed under the auspices of IGAD, the EU assumed a formal role in the implementation of the agreement.

The EU also adopted restrictive measures, in contrast to the UN, which failed to reach an agreement on this issue. Following the July 2011 Council Decision, which amended the arms embargo to cover both Sudan and South Sudan, in 2014 the EU adopted the Council Regulation concerning restrictive measures in respect of the situation in South Sudan ${ }^{38}$ (which provided the introduction of sanctions against 2 persons) and separately Council Regulation concerning restrictive measures given the situation in Sudan (imposing sanctions against 4 persons) ${ }^{39}$. What is interesting is the fact that although both documents maintained the arms embargo, the supply of non-lethal military equipment was exempted from the arms embargo. Besides, according to the Conflict Armament Research ${ }^{40}$, the restrictions meant little. Small arms and ammunition from the EU member states that were supposed to be exported to Uganda, South Sudan's neighbor, ended up in the hands of Sudan People's Liberation Army which provoked more violence and mass atrocities.

37 Zwan, J.: Evaluating the EU's role and challenges in Sudan and South Sudan Sudan and South Sudan Case Study. Initiative for Peacebuilding - Early Warning Analysis to Action (IfPEW) Report, The International Alert, Brussels, 2011, p. 18. [https://www.international-alert. org/sites/default/files/publications/092011IfPEWSudan_0.pdf], accessed on 17/12/2019.

38 Council Regulation No 747/2014 of 10 July 2014 concerning restrictive measures in view of the situation in Sudan, [https://eur-lex.europa.eu/legal-content/EN/TXT/PDF/?uri=CELEX:32014R0748], accessed on 17/12/2019.

39 Council Regulation No 748/2014 of 10 July 2014 concerning restrictive measures in respect of the situation in South Sudan, [https://eur-lex.europa.eu/legal-content/EN/TXT/PDF/?uri=CELEX:32014R0747\&from=EN], accessed on 17/12/2019.

40 Conflict Armament Research. Sudanese Stockpiles and Regional Weapon Diversion, London, 2017, p. 10, [file:///D:/\%D0\%97\%D0\%B0\%D0\%B3\%D1\%80\%D1\%8 3\%D0\%B7\%D0\%BA\%D0\%B8/Sudanese-Stockpiles-and-Regional-Weapons-Diversions-1\%20(1).pdf], accessed on 17/12/2019. 


\subsection{THE MYANMAR CASE}

The Rohingya is a group of heavily persecuted Muslims mainly residing within the Rakhine State in the Buddhist-majority nation of Myanmar. According to the United Nations High Commissioner for Refugees, around 200000 Rohingya have fled Myanmar in just the last five years.

The first document that condemns the actions of Myanmar military and security forces towards Rohingya was adopted by the Council in February 2018, in which the EU classifies the situation around the Muslim community in the Rakhine State as "widespread, systematic grave human rights violations" Following the Council Conclusions, the European Parliament in the resolution of 14 June 2018 points at "serious human rights violations" in Myanmar and expresses support to investigations into alleged atrocity crimes in the Rakhine State ${ }^{42}$

As for the actual tools, the EU response to the situation in Myanmar does not differ a lot from the one in South Sudan. The humanitarian aid again has become the primary tool at the disposal of the EU to provide assistance to the affected population. In 2018, the European Union has allocated $€ 9.4$ million in humanitarian aid, which is not targeted at solely Rohingya, but also includes Kachin and Shan states, as well as addresses the immediate needs of families affected by both natural disaster and conflict in Myanmar ${ }^{43}$. Additionally, in May 2018, the EU released $€ 40$ million to provide support to vulnerable Rohingya civilians across Rakhine State ${ }^{44}$. Meanwhile, the EU has provided $€ 688$ million under the Multi-annual Indicative Programmed 2014-2020 to the Myanmar government which has been accused by the Independent international fact-finding mission of "genocidal intent" against the Rohingya ${ }^{45}$. Mediation is another instrument the EU has at its disposal to address the situa-

41 Council Conclusions on Myanmar/Burma, of 26 February 2018, [http://data.consilium. europa.eu/doc/document/ST-6418-2018-INIT/en/pdf], accessed on 28/12/2019.

42 European Parliament Resolution of 14 June 2018 on the situation of Rohingya refugees, in particular the plight of children, [https://www.europarl.europa.eu/doceo/document/TA-8 2018-0261_EN.html], accessed on 28/12/2019.

43 European Commission Official Website: European Civil Protection and Humanitarian Aid Operations, [https://ec.europa.eu/echo/news/eu-commits-9-million-humanitarian-aid-most-vulnerable-families-myanmar_en], accessed on 28/12/2019.

44 European External Action Service (2018a), Factsheet. EU-Myanmar relations, Brussels, [https://eeas.europa.eu/headquarters/headquarters-homepage_en/4004/EU-Myanmar\%20relations], accessed on 28/12/2019.

45 Human Rights Council, (2018), Report of the independent international fact-finding mission on Myanmar, [https://www.ohchr.org/Documents/HRBodies/HRCouncil/FFM-Myanmar/A_HRC_39_64.pdf], accessed on 28/12/2019. 
tion in Myanmar. According to the statement by HR/VP Federica Mogherini ${ }^{46}$, the EU has been fully "mobilized politically and through extensive humanitarian assistance to help find a sustainable solution" to the crisis. Since 2017 the EU has been monitoring the implementation of the repatriation agreement between Myanmar and Bangladesh according to which Myanmar is obliged to create the conditions on the ground that will allow for a return of the refugees to their places of origin.

What differs the EU response to mass atrocities in Myanmar from the situation in Libya and South Sudan is the restrictive measures or, to be more accurate, the delay of the EU to impose them. In far 2013, just after the publication of the Human Rights Watch report pointing at the clear evidence of government complicity in ethnic cleansing and crimes against humanity against Muslims in Rakhine state, the EU lifted the last of its trade, economic and individual sanctions against Myanmar. The decision was made in response to Myanmar's new reform political program thus encouraging the transition of the country from almost half a century of military dictatorship and promoting democratic improvements. Only in 2018 following the declarations by Federica Mogherini regarding the EU willingness to impose sanctions against Myanmar ${ }^{47}$, the Council adopted the restrictive measures against Myanmar $/ \mathrm{Burma}^{48}$, which provided for entry-bans into the EU for seven members of the Burmese security forces who have been demonstrably involved in human rights violations against Rohingya as well as the freezing of their assets. The restrictive measures also included a ban on military cooperation with the armed forces and security forces and the arms embargo.

However, the effectiveness of sanctions can be questioned in view of their possible impact on bilateral trade with the EU. The EU ranked as the fourth biggest trade partner of Myanmar (after China, Thailand, and Singapore), accounting for $9 \%$ of the country's total trade while Myanmar is the EU's 75th

46 European Union (2017), Statement by High Representative/Vice-President Federica Mogherini on the signing of a bilateral repatriation agreement between the governments of Myanmar and Bangladesh. Brussels, [https://eeas.europa.eu/headquarters/ headquarters-homepage/36113/statement-hrvp-federica-mogherini-signing-bilateral-repatriation-agreement-between-governments_en], accessed on 28/12/2019.

47 European Union (2018), Remarks by High Representative/Vice-President Federica Mogherini at the press conference following the Foreign Affairs Council, Luxembourg, [https:// reliefweb.int/report/world/remarks-high-representativevice-president-federica-mogherini-press-conference-0], accessed on 30/12/2019.

48 Council Decision No 2018/900 of 25 June 2018 amending Decision 2013/184/CFSP concerning restrictive measures against Myanmar/Burma, [https://eur-lex.europa.eu/legal-content/EN/TXT/?uri=uriserv:OJ.LI.2018.160.01.0009.01.ENG\&toc=OJ:L:2018:160I:TOC], accessed on 30/12/2019. 
largest trading partner (accounting for $0.1 \%$ of the EU's total trade) ${ }^{49}$. Myanmar is a beneficiary of duty and quota-free access to the EU market through "Everything But Arms" (EBA) agreement of the Generalised Scheme of Preferences (GSP) which allows Myanmar to sell any products, except for arms and ammunition, to the EU market without facing tariffs or quotas. As the participation in EBA is conditional upon respect to fundamental rights, it provides the EU with another tool to exert pressure on Myanmar. The Council's conclusions on Myanmar, which expressed deep concern over the findings of the independent international fact-finding mission of the UN Human Rights Council which concluded that gross human rights violations were committed in Kachin, Rakhine and Shan States, in particular by the Myanmar Armed Forces, clearly stated that the respect of human and labor rights underpins the granting of trade preferences ${ }^{50}$. However, the significant economic ramifications for Myanmar, given the EU's role as a significant export market, including job losses and reduction of foreign investment, on the one hand, and possible losses for the EU in case of Myanmar's reorientation towards China make the withdrawal of trade preferences less and less likely to be implemented.

\footnotetext{
49 European Commission Official Website: Myanmar, [https://ec.europa.eu/trade/policy/ countries-and-regions/countries/myanmar/], accessed on 30/12/2019.

50 Council Conclusions on Myanmar/Burma, of 10 December 2018, [http://data.consilium. europa.eu/doc/document/ST-15033-2018-INIT/en/pdf], accessed on 30/12/2019.
} 


\section{FINDINGS}

A comparison of instruments in terms of EU responses to mass atrocities in three cases:

\begin{tabular}{|l|l|l|l|}
\hline & \multicolumn{1}{|c|}{ Libya } & \multicolumn{1}{|c|}{ South Sudan } & \multicolumn{1}{c|}{ Myanmar } \\
\hline $\begin{array}{l}\text { Terminology } \\
\text { used in the } \\
\text { EU official } \\
\text { documents }\end{array}$ & $\begin{array}{l}\text { Systemic } \\
\text { violations of } \\
\text { human rights }\end{array}$ & $\begin{array}{l}\text { Gross human } \\
\text { rights; serious } \\
\text { human rights } \\
\text { violations }\end{array}$ & $\begin{array}{l}\text { Systematic } \\
\text { grave human } \\
\text { rights violations; } \\
\text { alleged atrocity } \\
\text { crimes }\end{array}$ \\
\hline Humanitarian aid & $\begin{array}{l}\text { Provided } \\
\text { alongside } \\
\text { with the EU } \\
\text { Development } \\
\text { Aid }\end{array}$ & $\begin{array}{l}\text { Provided } \\
\text { alongside } \\
\text { with the EU } \\
\text { Development } \\
\text { Aid }\end{array}$ & $\begin{array}{l}\text { Provided } \\
\text { alongside } \\
\text { with the EU } \\
\text { Development } \\
\text { Aid }\end{array}$ \\
\hline $\begin{array}{l}\text { Restrictive } \\
\text { measures }\end{array}$ & $\begin{array}{l}\text { Targeted } \\
\text { sanction against } \\
\text { individuals and } \\
\text { arms embargo }\end{array}$ & $\begin{array}{l}\text { Targeted } \\
\text { sanction against } \\
\text { individuals and } \\
\text { arms embargo }\end{array}$ & $\begin{array}{l}\text { Targeted } \\
\text { sanction against } \\
\text { individuals and } \\
\text { arms embargo }\end{array}$ \\
\hline Mediation & $\begin{array}{l}\text { Not implemented } \\
\text { within the period } \\
\text { analyzed }\end{array}$ & $\begin{array}{l}\text { Agreement on } \\
\text { the Resolution } \\
\text { of the Conflict in } \\
\text { South Sudan }\end{array}$ & $\begin{array}{l}\text { Repatriation } \\
\text { Agreement } \\
\text { between the } \\
\text { governments of } \\
\text { Myanmar and } \\
\text { Bangladesh }\end{array}$ \\
\hline $\begin{array}{l}\text { CSDP military } \\
\text { operation }\end{array}$ & $\begin{array}{l}\text { Initiated but not } \\
\text { implemented }\end{array}$ & Not implemented & Not implemented \\
\hline $\begin{array}{l}\text { Withdrawal of } \\
\text { trade preferences }\end{array}$ & Not available & Not available & $\begin{array}{l}\text { Initiated but } \\
\text { not approved } \\
\text { within the period } \\
\text { analyzed }\end{array}$ \\
\hline
\end{tabular}

The findings of this paper summarized below offer an insight into the EU's capacity to respond to three mass atrocity situations.

Firstly, three cases demonstrate that the EU's language remains cautious, often referring to serious violations of human rights and humanitarian law, rather than "genocide" or "crimes against humanity". So far the EU has classified the situation in South Sudan as widespread "systemic abuse" and the European 
Parliament resolution of 14 June 2018 on the situation of Rohingya refugees refers to "alleged mass atrocities" committed by Myanmar security forces in Rakhine. Besides, the EU is reluctant to be first to acknowledge the fact that mass atrocities are occurring or that there is a serious risk of mass atrocities being perpetrated. Waiting for the warnings issued by other international actors the EU loses both the momentum and capacity to respond adequately to actual mass atrocity situations.

Secondly, three cases demonstrate that the EU's actions also remain cautious with a clear trend to integrate them into conflict management policy. The prevailing view in the EU is that mass atrocities do not require a special set of tools. Such a 'one-size-fits-all' approach deprives the EU of the required flexibility and capacity to act quickly. Some measures aimed at democratization or promotion of human rights might be relevant in conflict management, but seem inadequate in the actual mass atrocity cases. The desired impartiality in conflict management can also undermine the capacity of the EU to respond decisively in mass atrocity cases and protect victims from the crimes which are covered by R2P. Besides, the content analysis of the EU official documents reveals the divergence among three EU institutions in their preferences of tools and instruments available to the Union within R2P. With the European Parliament's preference for diplomatic and long-term developmental activities, the Commission's emphasis on trade instruments, the Council's focus on the importance of the CSDP component, the EU lacks a clear understanding of its scope of commitments under R2P.

Thirdly, the diversity in views among the member-states remains and becomes obvious when the issue of the military operation is discussed. There is no consensus over the use of measures to protect populations that require more ambitious actions. A number of the EU member-states are still unable or unwilling to contemplate the use of force to protect populations from atrocities thus making the implementation of the third pillar of R2P by the EU extremely difficult and contributing to the further division inside the EU. There is no EU military doctrine regarding the response to mass atrocities. Besides, there are no specific military scenarios that facilitate the execution of CSDP operations as the response to mass atrocities. This is partly because some member-states prefer to engage with the third pillar of R2P through other institutions, notably the NATO.

Fourthly, Myanmar's case demonstrates a clear shift in the EU foreign policy to a more pragmatic approach where the Union strives to strike a balance between external interests and a norm-based approach. The delay in imposing sanctions on Myanmar and reluctance to withdraw trade preferences raises several questions regarding the possible clash of the EU's interests with its obligations in terms of R2P. Following the logic of the EU global strategy 
2016, an ambitious trade agreement with a democratically regressive regime that might be also involved in perpetrating mass atrocities can be defended on the grounds that it will advance the resilience of the partner society. What falls outside of this logic is how to perform the responsibilities the EU had taken before the adoption of the global strategy 2016, e.g. R2P. By cooperating and trading with regimes that have been named and shamed as the perpetrators of mass atrocities by the world community, the EU itself risks to be named and shamed as a power which could have responded adequately but failed to do so.

\section{CONCLUSION AND RECOMMENDATIONS}

The content analysis of the official documents and statements reveal that the key EU's institutions diverge in their understanding of the scope of the EU's commitment under R2P. The comparative analysis of the instruments in terms of EU responses to mass atrocities in three cases - Libya, South Sudan, and Myanmar - highlights the risk of both over-promising and under-delivering. In light of the above said the EU's capacity to act quickly and decisively in response to mass atrocities based on the thorough examination of three cases seems weak. However, there is still room to do more to improve the implementation by the EU of its commitments within R2P.

The EU could establish an automatic set of events that trigger the introduction of particular tools. The negotiation of specific benchmarks concerning human rights obligations with the clear focus on the adoption of appropriate measures in case of a failure to meet such a benchmark will help the EU to give a clear message to the third countries regarding their losses in case of violation of human rights. Besides, the particular criteria should be introduced which will allow to withdraw the tool selected earlier without being later accused of subjectivity. This would prevent a situation when a decision regarding the provision of the development aid or withdrawal of sanctions by the EU (e.g. in Myanmar, the EU sanctions were lifted even despite the fact the international NGOs pointed at the on-going ethnic cleansing and crimes against humanity in the Rakhine State) can be adopted even despite any improvement of the situation. Such an approach will make the Union's policy more transparent and reduce the risk of delay in the selection of an appropriate tool.

The design of a separate mass atrocity policy beyond its conflict management policy is crucial for effective implementation by the EU of its commitments within R2P. It is time to draw a clear distinction between these two policies. The development by the EU of the separate mass atrocity policy which will be able to mitigate the risk factors that result in the commission of such crimes, as well as strengthening the further internal coordination among EU institutions will contribute to a better understanding of the EU's commitment to the 
$\mathrm{R} 2 \mathrm{P}$ and enhancing narrative coherence.

There are certain ways to improve the effectiveness of the human rights conditionality clause in the EU GSP scheme and thus turn foreign trade policy into an effective tool in response to mass atrocities that do not compete but complements the CFSP. Amongst these, wider use of ex-ante assessments and reliance on the reports of other credible international organizations, which could lead to the decision not to provide trade preferences until the concerned country demonstrates its compliance with the human rights, is required. The threshold enabling a country to be admitted to the GSP scheme should be increased. Taking into account the fact that the withdrawal of trade in the response of human right breach will result in restricted access to the EU market and inevitably affect social and economic human rights of millions in the concerned country, the focus should be placed on the assessment of the country's capacity to comply with the human rights clause before signing any trade agreements.

Summing up, the EU should ensure that its actions especially those with the focus on the CSDP component do not duplicate the actions of other actors such as the UN, NATO, etc. Any ambition to revise the intergovernmental bases of Union's foreign and defense policy and manage it as the single-market policies will inevitably leave the room for further disputes among member-states which before joining regional economic integration had integrated militarily within NATO. The EU has a wide range of instruments which despite being too modest in the actual mass atrocities, can be adequately used in the prevention or stabilization period. The EU should not strive to fill the niche which does not fit per se. By focusing on a limited number of key issues and promoting synergies with other actors involved in addressing the mass atrocity cases it is possible to achieve tangible and lasting results.

While these observations concern the EU's scope of commitments under R2P at the stage of response to mass atrocities, further research is required to assess the EU's capacity to implement its commitments within R2P at the stage of prevention and rebuilding where the EU's comprehensive approach to external conflict and crises plays a crucial role. 


\section{LITERATURE}

1. Biscop, S.: The European Security Strategy: A Global Agenda for Positive Power, Aldershot, Ashgate Publishing, 2005.

2. Bretherton C., Vogler, J.: The European Union as Global Actor, 2nd Edition. London, Routledge, 2006.

- DOI: https://doi.org/10.4324/9780203022672

3. Conflict Armament Research. Sudanese Stockpiles and Regional Weapon Diversion, London, 2017.

4. Dembinski, M., \&amp; Reinold, T.: Libya and the Future of the Responsibility to Protect - African and European Perspectives, Peace Research Institute Report, Frankfurt, 2011.

5. Fabbrini, S.: The European Union and the Libyan crisis. International Politics, 51(2), 2014.

- DOI: https://doi.org/10.1057/ip.2014.2

6. Fernanda, F., Youngs, R.: European Conflict Resolution Policies: Truncated Peacebuilding, Fride Working Paper, 2010.

7. Koenig, N.: The EU and the Libyan Crisis: In Quest of Coherence, The International Spectator, 46 (4) 2011.

- DOI: https://doi.org/10.1080/03932729.2011.628089

8. Manners, I.: Normative Power Europe Reconsidered: Beyond the Crossroads, Journal of European Public Policy, 13(2), 2006.

- DOI: https://doi.org/10.1080/13501760500451600

9. Nahlawi, Y. The responsibility to Protect in Libya and Syria: Mass Atrocities, Human Protection and International Law, Routledge, 2019.

- DOI: https://doi.org/10.4324/9780429461101

10. Spyer, J.: Europe and Iraq: Test Case for the Common Foreign and Security Policy, Middle East Review of International Affairs, 11(2), 2007.

11. Smith, K.: Still "Civilian Power EU”?, European Foreign Policy Unit Working Paper, No.1/2005.

12. Smith, K.: The EU and the Responsibility to Protect in an Illiberal Era. Dahrendorf Forum Working Paper, 3, 2018.

13. Stavridis, S., EU incoherence and inconsistency over Libya: evidence to the contrary. - Cahiers de la Méditerranée, 89, 2014.

14. Tocci, N.: Regional origins, global aspirations: the European Union as a global conflict manager, in: Stefan Wolff and ChristallaYakinthou (eds.), Conflict Management in Divided Societies. Theories and Practice, London and New York, Routledge, 2011. 
15. Wouters, J., De Man, Ph., Vincent, M.: The Responsibility to Protect: Where Does the EU Stand? Policy Brief. No. 10, 2008.

16. Zwan, J.: Evaluating the EU's role and challenges in Sudan and South Sudan Sudan and South Sudan Case Study. Initiative for Peacebuilding - Early Warning Analysis to Action (IfP-EW) Report, The International Alert, Brussels, 2011.

\section{DOCUMENTS AND REPORTS}

1. Council Conclusions on Myanmar/Burma, of 26 February 2018.

2. Council Conclusions on Myanmar/Burma, of 10 December 2018.

3. Council Conclusions on the EU's comprehensive approach, of 12 May 2014.

4. Council Decision No 2011/210/CFSP of 1 April 2011 on a European Union military operation in support of humanitarian assistance operations in response to the crisis situation in Libya (EUFOR Libya).

5. Council Decision No 2011/137/CFSP of 28 February 2011 concerning restrictive measures in view of the situation in Libya.

6. Council Decision No 2018/900 of 25 June 2018 amending Decision 2013/184/ CFSP concerning restrictive measures against Myanmar/Burma.

7. Council Press Release (2004), General Affairs and External Relations, Luxembourg.

8. Council Regulation No 747/2014 of 10 July 2014 concerning restrictive measures in view of the situation in Sudan.

9. Council Regulation No 748/2014 of 10 July 2014 concerning restrictive measures in respect of the situation in South Sudan.

10. Council Regulation No 2015/735 of 7 May 2015 concerning restrictive measures in respect of the situation in South Sudan, and repealing Regulation (EU) No $748 / 2014$.

11. Council Regulation No 204/2011 of 2 March 2011 concerning restrictive measures in view of the situation in Libya.

12. Council Report on the Implementation of the European Security Strategy (2008), Providing Security in a Changing World, Brussels.

13. European External Action Service (2018a), Factsheet. EU-Myanmar relations, Brussels.

14. European External Action Service (2018b), Statement on behalf of the EU and its Member States by Ambassador Joanne Adamson, Deputy Head of Delegation, at the UN General Assembly Debate on "The responsibility to protect and the prevention of genocide, war crimes, ethnic cleansing and crimes against humanity".

15. European Parliament (2011a), Resolution of 10 March 2011 on the Southern Neighbourhood, and Libya in particular. 
16. European Parliament (2011b), Resolution of 15 September 2011 on the situation in Libya.

17. European Parliament and Council (2013), Joint communication. The EU's comprehensive approach to external conflict and crises.

18. European Parliament, Council and Commission (2006), Joint statement by the Council and the representatives of the governments of the Member States meeting within the Council, the European Parliament and the Commission on European Union Development Policy. The European Consensus.

19. European Parliament, Recommendation to the Council of 18 April 2013 on the UN principle of the 'Responsibility to Protect' ('R2P').

20. European Parliament, Resolution of 13 November 2014 on the humanitarian situation in South Sudan.

21. European Parliament, Resolution of 14 June 2018 on the situation of Rohingya refugees, in particular the plight of children.

22. European Parliament, Resolution of 16 December 2015 on preparing for the World Humanitarian Summit: Challenges and opportunities for humanitarian assistance.

23. European Union (2003), A Secure Europe in a Better World: European Security Strategy, Brussels.

24. European Union (2011), Statement by Kristalina Georgieva, Commissioner for International Cooperation, Humanitarian Aid and Crisis Response, on the deteriorating humanitarian situation in Misrata, Libya.

25. European Union (2016), Shared Vision, Common Action: A Stronger Europe. A Global Strategy for the European Union Foreign and Security Policy. Luxembourg.

26. European Union (2017), Statement by High Representative/Vice-President Federica Mogherini on the signing of a bilateral repatriation agreement between the governments of Myanmar and Bangladesh, Brussels.

27. European Union (2018), Remarks by High Representative/Vice-President Federica Mogherini at the press conference following the Foreign Affairs Council, Luxembourg.

28. Human Rights Council, (2018), Report of the independent international fact-finding mission on Myanmar.

29. United Nations General Assembly (2005), Resolution № 60/1: 2005 World Summit Outcome.

30. United Nations Press Release (2013), Statement by Adama Dieng, United Nations Special Adviser on the Prevention of Genocide, and Jennifer Welsh, United Nations Special Adviser on the Responsibility to Protect, on the Situation in South Sudan. 


\section{ONLINE SOURCES}

1. [https://ec.europa.eu/echo/where/africa/south-sudan_en], accessed on 05/12/2019.

2. [https://ec.europa.eu/echo/where/africa/south-sudan_en], accessed on 05/12/2019.

3. [https://ec.europa.eu/echo/news/eu-commits-9-million-humanitarian-aid-most-vulnerable-families-myanmar_en], accessed on 28/12/2019.

4. [https://ec.europa.eu/trade/policy/countries-and-regions/countries/myanmar/], accessed on 30/12/2019. 